\title{
Perturbation of a Tethyan coastal environment during the Paleocene-Eocene thermal maximum in Tunisia (Sidi Nasseur and Wadi Mezaz)
}

\author{
Peter Stassen ${ }^{\mathrm{a}, *}$, Christian Dupuis $^{\mathrm{b}}$, Etienne Steurbaut ${ }^{\mathrm{a}, \mathrm{c}}$, Johan Yans ${ }^{\mathrm{d}}$, Robert P. Speijer ${ }^{\mathrm{a}}$ \\ a Department of Earth and Environmental Sciences, K.U.Leuven, Celestijnenlaan 200E, B-3001 Leuven, Belgium \\ ${ }^{\mathrm{b}}$ Faculté Polytechnique de Mons, Université de Mons, Rue de Houdain 9, B-7000 Mons, Belgium \\ c Department of Paleontology, Royal Belgian Institute of Natural Sciences, Vautierstraat 29, B-1000, Brussels, Belgium \\ ${ }^{d}$ Department of Geology, FUNDP, UCL-Namur, Rue de Bruxelles 61, B-5000 Namur, Belgium
}

\section{A R T I C L E I N F O}

\section{Article history:}

Received 11 April 2011

Received in revised form 1 December 2011

Accepted 12 December 2011

Available online 21 December 2011

\section{Keywords:}

Benthic foraminifera

Tunisia

Paleocene-Eocene thermal maximum

Paleoenvironment

Sea level

Dysoxia

\begin{abstract}
A B S T R A C T
Despite the large number of studies on the Paleocene-Eocene thermal maximum (PETM), the knowledge of environmental and biotic responses in shallow marine environments remains quite poor. Benthic foraminiferal assemblages of the Sidi Nasseur and Wadi Mezaz sections in Tunisia were studied quantitatively and the paleoecologic interpretations provide new insights into the complex relationship between PETM global warming and perturbations of shallow marine settings. These sections expose upper Paleocene to lower Eocene shales and marls of the El Haria Formation up to the phosphate layers of the Chouabine Formation underlying the El Garia limestones. The Sidi Nasseur section contains a more complete and expanded Paleocene-Eocene boundary interval compared to Wadi Mezaz, although being truncated at the top. The Wadi Mezaz section contains a more complete post-PETM interval. The studied interval can be subdivided into a sequence of 4 biofacies, representing respectively a latest Paleocene biofacies, two PETM biofacies and one post-PETM Eocene biofacies.

The latest Paleocene biofacies 1 consists of numerous calcareous benthic foraminifera (e.g. Anomalinoides midwayensis, Frondicularia aff. phosphatica and various Bulimina and Lenticulina species), abundant noncalcareous taxa (Haplophragmoides) and rare planktic foraminifera, indicating a slightly hypersaline eutrophic inner neritic to coastal environment, regularly interrupted by oxygen deficiency (moderate dysoxia). During the latest Paleocene, this highly productive environment shallowed as indicated by the increasing abundances of $A$. midwayensis. The variable dominance of non-calcareous agglutinated taxa in biofacies 1 indicates post-mortem dissolution effects. The TOC $\delta^{13} C_{\text {org }}$ record reveals a sharp negative excursion, marking the base of the Eocene. In general, the absence of lithologic changes, an increasing sedimentation rate and absence of reworking indicate that the initial part of the PETM is complete and expanded in the Sidi Nasseur section. A sharp faunal turnover coincides with this negative $\delta^{13} \mathrm{C}_{\text {org }}$ excursion and is characterized by the disappearance or diminution of common Paleocene taxa in this area. During the PETM, benthic foraminifera are less abundant and consist of opportunistic non-calcareous taxa together with deeper dwelling (middle neritic) lagenids and buliminids (biofacies 2 and 3). Planktic foraminifera, dominated by flat-spired Acarinina (mainly A. multicamerata), become more abundant, as observed in many open marine sequences worldwide. All these faunal parameters suggest more stressed probably severe dysoxic sea floor conditions within a transgressive phase during the onset of the PETM. An estimation of the total duration of the Sidi Nasseur PETM interval is difficult to establish, yet the lack of recovery carbon isotope values suggests that the preserved PETM interval reflects only a part of the CIE "core". The top of the PETM interval is truncated due to local (?) erosion during the early Eocene. The Eocene recovery fauna is mainly composed of Lenticulina and Stainforthia species (biofacies 4), indicating restricted coastal to hyposaline lagoonal eutrophic conditions, distinctly different from earlier environmental conditions.
\end{abstract}

(c) 2011 Elsevier B.V. All rights reserved.

\footnotetext{
* Corresponding author at: Biogeology Research Group, Department of Earth and Environmental Sciences, K.U. Leuven, Celestijnenlaan 200E, B-3001 Leuven, Belgium. Tel.: +32163264 52; fax: +3216322980.

E-mail addresses: Peter.Stassen@ees.kuleuven.be (P. Stassen),

Christian.Dupuis@umons.ac.be (C. Dupuis),Etienne.Steurbaut@naturalsciences.be

(E. Steurbaut), jyans@fundp.ac.be (J. Yans), Robert.Speijer@ees.kuleuven.be

(R.P. Speijer).
}

\section{Introduction}

The Paleocene-Eocene thermal maximum (PETM), 55.8 Ma ago, was a geologically brief ( $170 \mathrm{kyr}$; Röhl et al., 2007) episode of globally elevated temperatures, superimposed on the long-term late Paleocene and early Eocene warming trend that culminated in the highest ocean temperatures of the Cenozoic (EECO, Early Eocene 